\title{
Pemberdayaan Masyarakat Di Kelurahan Wonosari Melalui Olahraga
}

\author{
Qorby Haqqul Adam \\ Universitas Islam Negeri Walisongo Semarang \\ Email :qhadam@walisongo.ac.id
}

\begin{abstract}
Wonosari is one of the sub-districts in Ngaliyan district, Semarang city. The community in Wonosari Village is a suburban community group. They have low insight and awareness in doing sports. Sports can be used as a development of the potential, character and active role of humans in community life. Sports has benefits in all fields in the community such as education, culture, social, economic and health. Humans have been preoccupied with pragmatism in this age. They do not understand that moving is very important for health and is the most valuable asset they can have. Health is grouped into four types, physically, spiritually, socially and economically healthy. Lack of physical activity and exercise will cause adverse effects on the body. Wonosari people who have solid activities can do some physical activities to just relax muscles and blood circulation such as: cycling, walking early in the morning, sweeping the floor, mutual cooperation in the village every day, and others. If you have enough free time someone can exercise. The types of sports that can be done in the Wonosari Urban community include rhythmic gymnastics, soccer, volleyball, badminton and relaxing walking. Sports also have benefits for physical fitness, achieving spiritual, social and economic health in humans.
\end{abstract}

Abstrak: Wonosari merupakan salah satu Kelurahan di Kecamatan ngaliyan Kota Semarang. Masyarakat di Kelurahan Wonosari merupakan kelompok masyarakat suburban. Mereka mempunyai wawasan dan kesadaran yang rendah dalam melakukan olahraga. Olahraga dapat dijadikan sebagai pengembangan potensi, karakter dan peran aktif manusia dalam kehidupan bermasyarakat. Olahraga mempunyai manfaat dalam segala bidang di lingkungan masyarakat seperti pendidikan, budaya, sosial, ekonomi dan kesehatan. Manusia telah disibukkan dengan aktivitas pragmatisme pada zaman ini. Mereka tidak mengerti bahwa bergerak sangat penting bagi kesehatan dan menjadi harta yang paling berharga yang dapat mereka miliki. Kesehatan dikelompokkan menjadi empat macam, sehat secara jasmani, rohani, sosial dan ekonomi. Kurangnya melakukan aktivitas fisik dan olahraga akan mengakibatkan efek yang kurang baik bagi tubuh. Masyarakat Wonosari yang mempunyai kegiatan padat dapat melakukan beberapa aktivitas fisik untuk sekedar melemaskan otot maupun melancarkan peredaran darah seperti: bersepeda, jalan pagi, menyapu lantai, gotong royong di desa setiap ahad, dan lainnya. Jika memiliki waktu luang yang cukup banyak seseorang dapat melakukan olahraga. Jenis olahraga yang dapat dilakukan di lingkungan masyarakat Kelurahan Wonosari antara lain senam 
ritmik, sepakbola, bola voli, badminton dan jalan santai. Olahraga juga mempunyai manfaat untuk kebugaran jasmani, meraih kesehatan secara rohani, sosial dan ekonomi pada manusia.

Kata Kunci: pemberdayaan, masyarakat, wonosari, olahraga.

\section{PENDAHULUAN}

Kabupaten Banyak sekali kasus yang terjadi di masyarakat dikarenakan pola hidup masyarakat yang tidak baik. Meningkatnya masyarakat yang menjadi pecandu narkoba, makin maraknya geng motor, pergaulan bebas dan maraknya pencurian merupakan beberapa contoh kasus negatif yang terjadi di lingkungan masyarakat. Olahraga dapat menjadi salah satu solusi dalam mengatasi permasalahan tersebut. Olahraga juga dapat menjadi sarana dalam pembangunan bangsa, khususnya pembangunan dalam bidang jasmani dan rohani. Hal tersebut sesuai dengan hakikat olahraga sebagai refleksi kehidupan masyarakat suatu bangsa dan terdapat nilai-nilai luhur suatu bangsa. Olahraga juga merupakan proses sistematik yang berupa kegiatan atau usaha yang dapat mendorong mengembangkan dan membina potensi jasmani dan rohani seseorang sebagai perorangan atau anggota masyarakat dalam bentuk permainan, perlombaan/pertandingan dan prestasi puncak dalam pembentukan manusia Indonesia seutuhnya yang berkualitas berdasarkan Pancasila. Pemerintah sedang giatnya melakukan GERMAS atau Gerakan Masyarakat Sehat. Salah satu manfaat GERMAS ini diterapkan di Kelurahan Wonosari dengan tujuan membina dan mengembangkan potensi pada masyarakat Kelurahan Wonosari Kecamatan ngaliyan Kota Semarang.

Masyarakat di Kelurahan Wonosari mempunyai banyak sekali potensi untuk dikembangkan. Hal ini sangat dipahami oleh pihak Kecamatan, pihak Kelurahan serta beberapa tokoh masyarakat di lingkungan Wonosari ngaliyan. Sebagai contoh adalah pada gelaran Porwakos atau Pekan Olahraga Warga Kota Semarang bulan Mei tahun 2018 Kelurahan Wonosari mengirimkan beberapa atlet mewakili Kecamatan Ngaliyan untuk bertanding pada beberapa cabang olahraga, misalnya sepakbola, futsal, badminton, bola voli dan pencak silat. Hal ini menunjukkan betapa besar potensi yang ada pada Kelurahan Wonosari. Akan tetapi untuk memberdayakan masyarakat di Kelurahan Wonosari tidak harus dengan menggerakkan olahraga akan tetapi dapat diawali dengan hal yang ringan seperti melakukan aktivitas fisik yang dilakukan rutin. Pengertian antara olahraga dan aktivitas fisik seringkali disalahartikan oleh sebagian orang. Banyak sekali orang yang beranggapan bahwa antara olahraga dan aktivitas fisik merupakan hal yang sama, akan tetapi keduanya merupakan dua hal yang berbeda. Olahraga 
mempunyai pengertian yang lebih luas. Olahraga merupakan sebuah aktivitas fisik yang dilakukan oleh beberapa anggota tubuh secara teratur dan terencana yang bertujuan untuk meningkatkan kebugaran jasmani. Sedangkan aktivitas fisik merupakan aktivitas yang dilakukan oleh organ anatomi (otot, tulang dsb) yang memerlukan pengeluaran energi.

Kenyataan yang terjadi pada zaman ini adalah manusia terlalu disibukkan dengan kegiatan yang bersifat pragmatisme. Efek negatif dari globalisasi lebih banyak dari hal positif yang dapat diraih dari globalisasi. Termasuk yang terjadi didaerah Kelurahan Wonosari. Masyarakat tidak sadar bahwa yang mereka lakukan menjadi sebuah bom waktu bagi masa depannya. Kesehatan merupakan sebuah masa depan yang harus dicapai. Jika kita sehat maka akan memperlancar segala aktivitas kita. Kesehatan dapat diwujudkan melalui olahraga. Olahraga menjadi sangat penting karena sesuai dengan kebutuhan dasar manusia dan dalam kehidupan yang tidak hanya melibatkan aspek jasmani, tetapi juga aspek rohani, aspek sosial dan bahkan aspek ekonomi. Dengan demikian menjadi semakin jelas betapa luasnya lingkup permasalahan kesehatan olahraga yaitu benar-benar meliputi seluruh aspek kehidupan manusia. Oleh karena ini pemerintah di Kecamatan Ngaliyan dan Kelurahan Wonosari saling bekerja sama untuk mewujudkan masyarakat yang berbudaya olahraga.

\section{KARAKTERISTIK MASYARAKAT KELURAHAN WONOSARI}

Beberapa Istilah masyarakat berasal dari baha arab Syaraka yang berarti ikut serta dan berpartisipasi. Dalam istilah ilmiah masyarakat adalah saling berinteraksi. Masyarakat merupakan golongan atau kelompok yang terdiri dari beberapa manusia yang saling mempengaruhi satu dengan lainnya. Golongan manusia tersebut memiliki hubungan sosial, tatanan hidup, norma-norma, adat istiadat yang sama dan hidup bersama dalam suatu wilayah. Syarat yang harus dipenuhi dalam kehidupan bermasyarakat adalah ada kumpulan manusia, telah bertempat tinggal dalam waktu yang lama dan dalam suatu daerah tertentu, ada aturan-aturan atau undang-undang yang berlaku untuk mengatur kepada kepentingan dan tujuan bersama dalam waktu yang relatif lama.

Kecamatan ngaliyan mempunyai sepuluh Kelurahan. Beberapa Kelurahan tersebut diantaranya : bambankerep, bringin, kalipancur, ngaliyan, podorejo, purwoyoso, tambakaji, wates dan Wonosari. Kelurahan Wonosari merupakan kelurahan yang terletak paling barat dari Kecamatan Ngaliyan. Kelurahan Ngaliyan berbatasan langsung dengan Kecamatan Kaliwungu Kabupaten Kendal. Kelurahan Wonosari merupakan daerah yang berada pada ketinggian 330 meter diatas permukaan laut dan mempunyai luas wilayah sekitar 323,549 ha 
dengan batas wilayah sebelah utara : jalan pantura semarang-kendal, sebelah selatan : kelurahan gondoriyo, sebelah barat : kecamatan kaliwungu kabupaten kendal dan sebelah timur : kelurahan tambak aji. Berdasarkan data sensus dari pemerintah kelurahan Wonosari pada tahun 2017 terdapat beberapa contoh penyakit yang diderita masyarakat kelurahan Wonosari diantaranya: diabetes mellitus, infeksi saluran kemih, wasir, kolesterol tinggi, asam urat, sembelit dan lain-lain. Beberapa penyakit diatas dialami oleh banyak anggota masyarakat yang tersebar pada rukun tetangga (RT), tidak mengenal golongan atas dan bawah. Mayoritas masyarakat di Kelurahan Wonosari merupakan etnis jawa yang adat dan istiadatnya hampir sama dan kemungkinan terjadi penyebaran penyakit yang sama karena kebiasaan masyarakat yang kurang sehat tersebut.

Pemerintah di kelurahan Wonosari mempunyai program pola hidup sehat mulai anak-anak. Dalam kedudukannya di masyarakat anak adalah masa depan dari suatu masyarakat. Masuknya arus globalisasi pada zaman ini mengakibatkan dampak yang baik dan buruk terhadap anak. Akan tetapi anak lebih mendapatkan dampak yang buruk jika dilihat dari segi pertumbuhan jasmaninya. Efek jangka panjang adalah masuknya beberapa penyakit yang seharusnya memiliki resiko yang sedikit untuk terjadi pada anak, seperti diabetes, obesitas sampai penyakit jantung. Bahkan telah terjadi pada usia remaja. Istilah remaja adalah golongan manusia muda yang memerlukan pembinaan dan pengembangan ke arah yang lebih baik agar dapat melanjutkan dan mengisi pengembangan yang telah berlangsung. Kedudukan remaja atau pemuda dalam masyarakat adalah sebagai mahluk moral, mahluk sosial, artinya mempunyai etika dan dijadikan sebagai standar moral kehidupan bangsa. Di masyarakat, pemuda merupakan satu identitas yang potensial. Kedudukannya sangat strategis sebagai penerus perjuangan bangsa dan bagi pembangunan bangsa. Agar dapat memaksimalkan potensinya pemuda harus terus dikawal oleh orang dewasa yang lebih tua dalam kehidupan bermasyarakat.

\section{PEMBERDAYAAN OLAHRAGA DI KELURAHAN WONOSARI}

Pemberdayaan Masyarakat dapat diartikan sebagai suatu proses yang membangun manusia atau masyarakat melalui pengembangan kemampuan masyarakat, perubahan perilaku masyarakat dan pengorganisasian masyarakat. Inti dari pemberdayaan masyarakat merupakan strategi untuk mewujudkan kemampuan dan kemandirian masyarakat. Pada masyarakat di Kelurahan Wonosari pemberdayaan dikhususkan pada kelompok usia dini. Pemerintah Kelurahan Wonosari rajin melakukan gerak jalan santai setiap ahad pagi. Ada 
beberapa kelompok masyarakat pada RW atau rukun warga yang bahkan telah mempunyai komunitas bersepeda.

Pemberdayaan tidak bersifat selamanya, melainkan sampai target masyarakat mampu untuk mandiri dan kemudian dilepas untuk mandiri. Pemberdayaan pasti melalui suatu proses belajar hingga mencapai status yang mandiri. Meskipun demikian dalam rangka menjaga kemandirian tersebut tetap dilakukan pemeliharaan semangat, kondisi, dan kemampuan secara terus menerus supaya tidak mengalami kemunduran lagi. Dalam upaya memberdayakan masyarakat dapat dilakukan melalui beberapan cara, yaitu: (1) menciptakan suasana atau iklim yang memungkinkan potensi masyarakat berkembang (enabling), (2) memperkuat potensi atau daya yang dimiliki masyarakat (empowering), (3) memberdayakan mengandung pula arti melindungi (protecting). Pada ibu-ibu di kelurahan wonosari mempunyai grup tenis meja walaupun tidak terlalu banyak pemainnya kurang lebih 4 sampai 5 orang yang rutin latihan. Ibu-ibu juga mempunyai grup senam aerobik. Di RW 2 misalnya, terdapat program dari salah satu dokter keluarga yaitu dr. $\mathrm{Hj}$. Sri hartiningsih yang menyelenggarakan senam sehat setiap ahad keempat tiap bulan. Program tersebut sangat bagus karena mengarahkan warga masyarakat untuk gemar berolahraga. Manfaat lainnya sebagai wadah untuk menjalin relasi antar keluarga dan sebagai pemuas kebutuhan ekonomi.

Pemberdayaan masyarakat merupakan sebuah konsep pembangunan ekonomi, budaya dan pendidikan yang merangkum nilai-nilai sosial. Pemberdayaan Masyarakat merupakan salah satu dari peran pemerintah secara normatif dan kelembagaan. Pemerintah dan masyarakat memiliki peran dalam memajukan kehidupan bersama. Peran pemerintah dalam hal ini peran dalam hal pemberdayaan masyarakat dapat berjalan secara baik apabila masyarakat juga melakukan peran-peran secara kelembagaan pula. Setiap hari ahad, RW 5 juga rutin mengadakan gemr berbulutangkis. Di RW 5 kelurahan wonosari terdapat gor bulutangkis yang bernama Gor Hamas dan dimiliki oleh Bapak H. Masrokan. Terdapat perkumpulan PB Hamas yang telah memiliki sejumlah atlet mulai dari usia 7 tahun sampai usia 20 tahun dan bahkan usia melebihi 30 tahun. Bulutangkis merupakan salah satu cabang olahraga unggulan yang dimiliki Kelurahan Wonosari selain olahraga beregu lainnya seperti sepakbola, bola voli dan futsal. Di RW 7 dan 11 Kelurahan Wonosari terdapat lapangan bola voli. Kondisi lapangan bola voli tersebut tidak dapat dikategorikan baik tetapi juga tidak dapat dikategorikan kurang baik. Walaupun seperti itu, tetap masih ada masyarakat yang menggunakan lapangan tersebut untuk sekedar melampiaskan hobi. 
Tujuan yang ingin dicapai dari pemberdayaan adalah untuk membentuk individu dan masyarakat menjadi mandiri. Kemandirian tersebut meliputi kemandirian berfikir, bertindak dan mengendalikan apa yang mereka lakukan. Kemandirian masyarakat merupakan kondisi yang dialami oleh masyarakat yang ditandai oleh kemampuan untuk memikirkan, memutuskan serta melakukan sesuatu yang dipandang tepat demi mencapai pemecahan masalah yang dihadapi dengan menggunakan kemampuan yang terdiri atas kemampuan kognitif, afektif dan psikomotor. Berbagai sarana, prasarana dan program yang dimiliki oleh masyarakat Keluruhan Wonosari sangat membantu untuk mewujudkan masyarakat Kelurahan Wonosari yang mandiri walaupun memang masih terdapat berbagai kekurangan. Kekurangan tersebut dapat dilihat dari berbagai fasilitas yang ada sehingga masih banyak masyarakat yang kurang tertarik untuk melakukan olahraga atau sekedar melakukan aktivitas fisik ringan sehingga timbul berbagai penyakit di lingkungan Kelurahan Wonosari.

Semakin banyak masyarakat yang melakukan olahraga akan semakin meningkatkan derajad hidup manusia dilingkungan terebut. Olahraga adalah suatu bentuk aktivitas fisik yang terencana dan terstruktur yang melibatkan gerakan tubuh berulang-ulang dan ditujukan untuk meningkatkan kebugaran jasmani. Masyarakat melakukan olahraga dengan berbagai tujuan, seperti menjaga kebugaran jasmani, pemuasan hobi, rehabilitasi dan sarana prestasi. Ada beberapa warga di RW 3 kelurahan Wonosari yang memiliki kecanduan yang berat terhadap rokok mendapatkan manfaat dari berolahraga rutin seminggu 3 kali. Ini merupakan salah satu pengaruh dari melakukan olahraga secara rutin yaitu sebagai sarana untuk rehabilitasi. Merokok sangat tidak baik untuk kesehatan, apapun alasannya. Berbagai bahan kimia yang terkandung didalam rokok dapat memicu berbagai sel kangker dan penyakit lainnya untuk berevolusi. Memang, evolusi berbagai penyakit tersebut berbeda tiap orangnya. Tetapi ini tidak dapat dijadikan alasan seseorang untuk mencoba bahkan menikmati rokok. Warga yang pernah menjadi pecandu rokok mengaku mengalami berbagai perubahan setelah melakukan olahraga minimal seminggu tiga kali dalam seminggu dalam rentang waktu 3 bulan.

Ada beberapa kelompok lansia di RW 1 yang melakukan jalan santai rutin setiap pagi selama minimal 30 menit mengalami perubahan yang baik bagi gairah aktivitas setiap hari. Hal seperti itu dapat dikatakan bahwa aktivitas jasmani yang dilakukan mempunyai manfaat bagi rohani dan menjaga fungsi syaraf, fleksibilitas tubuhpun terjaga dengan baik. Selain itu aktivitas fisik apapun yang dilakukan harus selalu dilaksanakan secara terstruktur dan terencana. Beberapa aktivitas tersebut diantaranya: mencuci baju, menyapu, mencangkul sawah atau 
kebun setiap hari. Aktivitas jasmani dapat diperdalam lagi pada saat pembelajaran Pendidikan Jasmani, Olahraga dan Kesehatan di sekolah atau dapat juga mengundang pakar olahraga setiap minggu. Aktivitas jasmani sangat membantu meningkatkan perkembangan karakter individu. Adapun tujuan pendidikan jasmani menurut Depdiknas (2003:6) adalah : (1) meletakkan landasan karakter yang kuat melalui internalisasi nilai dalam pendidikan jasmani, (2) menumbuhkan kemampuan berpikir kritis melalui tugas-tugas pembelajaran pendidikan jasmani, (3) mengembangkan sikap sportif, disiplin, bertanggung jawab, kerjasama, percaya diri dan demokratis melalui aktivitas jasmani, (4) mengembangkan sikap sportif, jujur, disiplin, bertanggung jawab, kerjasama, percaya diri, (5) mengembangkan kemampuan gerak dan keterampilan berbagai macam permainan dan olahraga. Beberapa tujuan tersebut merupakan target pemerintah Kelurahan Wonosari untuk menjadikan Kelurahan Wonosari menjadi Percontohan Kelurahan Sehat. Paling tidak, seluruh warga memahami pentingnya memperoleh badan yang bugar setiap hari.

Kebugaran jasmani merupakan kemampuan seseorang untuk melakukan aktivitas tanpa mengalami kelelahan yang berarti dan masih mempunyai cadangan tenaga untuk melakukan aktivitas selanjutnya. Seseorang yang mempunyai kebugaran jasmani yang baik pasti mempunyai tingkat konsentrasi yang baik pula sehingga akan memudahkan dalam melakukan aktivitas setiap hari seperti belajar dan bekerja setiap hari. Untuk dapat mempunyai kebugaran jasmani yang baik seseorang harus selalu berlatih dan menerapkan pola hidup yang sehat. Terdapat 10 komponen kebugaran jasmani pada manusia. Komponen-komponen tersebut antara lain : Kekuatan, Daya Tahan, Kecepatan, Kelincahan, Power, Koordinasi, Keseimbangan, Ketepatan (Akurasi), Fleksibilitas dan Waktu Reaksi. Ada beberapa warga di Kelurahan Wonosari yang merupakan seorang atlet. Contohnya adalah Erwin (RW 2), Prasetyo Adi (RW 11), Bayu Irawan (RW 9) ketiganya merupakan atlet olahraga futsal yang mewakili Kelurahan Wonosari di berbagai kejuaraan. Kebetulan pada bulan Mei tahun 2018 yang lalu mereka termasuk dalam anggota tim futsal yang menjadi juara pada ajang Porwakos 2018. Sangat mutlak jika seseorang ingin mencapai prestasi yang maksimal memiliki komponen kebugaran jasmani yang baik.

Kekuatan merupakan kemampuan seseorang untuk mengatasi atau melawan beban. Kekuatan pada manusia dibagi menjadi beberapa bagian. Kekuatan otot perut, dapat dilatih dengan melakukan gerakan sit up. Kekuatan otot lengan, dapat dilatih dengan melakukan gerakan push up dan pull up. Kekuatan otot punggung, dapat dilatih dengan melakukan gerakan back $u p$. Kekuatan otot tungkai, dapat dilatih dengan melakukan gerakan squad jump. 
Daya Tahan dikenal 2 macam daya tahan yaitu: Daya tahan umum adalah kemampuan seseorang dalam mempergunakan sistem jantung, paru-paru dan peredaran darah secara efektif dan efisiensi untuk menjalankan kerja secara terus menerus yang melibatkan kontraksi sejumlah otot-otot dengan intensitas tinggi dalam waktu yang lama, daya tahan otot adalah kemampuan seseorang dalam mempergunakan otot-ototnya untuk berkontraksi secara terus menerus dalam waktu yang relatif lama dengan beban tertentu. Kecepatan adalah suatu kemampuan untuk menghasilkan gerakan tubuh dalam keadaan waktu yang sesingkat mungkin, kecepatan bersifat lokomotor atau berpindah tempat dan gerakannya bersifat siklis (satu jenis gerakan yang dilakukan berulang-ulang seperti lari). Power adalah gabungan antara kekuatan dan kecepatan atau pergerakan gaya otot maksimal untuk melakukan suatu kerja dengan kecepatan maksimal dengan waktu secepat-cepatnya. Kelincahan adalah kemampuan merubah arah atau posisi tubuh dengan cepat. Fleksibilitas adalah keleluasaan gerak otot dan sendi. Keseimbangan adalah kemampuan mempertahankan sikap tubuh. Koordinasi adalah kemampuan seseorang untuk mengintrogasi bermacam-macam gerakan yang berbeda kedalam pola gerak tunggal secara efektif. Kecepatan Reaksi adalah waktu tersingkat yang dibutuhkan untuk menanggapi rangsangan. Ketepatan adalah kemampuan seseorang untuk mengendalikan gerak bebas terhadap suatu sasaran. Bentuk aktivitas atau latihan dari berbagai komponen kebugaran jasmani tersebut dapat dilakukan diseluruh wilayah kelurahan Wonosari mulai dari area datar sampai perbukitan.

Ada beberapa kelompok bentuk aktivitas fisik di masyarakat Kelurahan Ngaliyan: (1) Kelompok malas bergerak (sedentary), mereka sedikit melakukan aktivitas fisik atau bahkan tidak ada aktivitas fisik sama sekali. Kelompok ini adalah mereka berada pada ditingkat yang sangat mungkin memperoleh lebih banyak penyakit dibanding kelompok lainnya, rentang usianya lebih pendek dan kulitas hidupnya relatif rendah. (2) Tingkat olahraga dengan intesitas rendah, untuk kebugaran dan umur panjang. Mereka yang berada tingkat ini cenderung akan menikmati manfaat nyata lebih tinggi dari mereka yang termasuk golongan pertama, artinya resiko terserang penyakit lebih rendah dan umurnya lebih panjang. (3) Tingkat olahraga seorang atlit yang mendekati tingkat kebugaran yang diperlukan untuk pertandingan, tetapi tidak overtraining atau latihan yang sangat berlebihan yang juga dapat berbahaya bagi kesehatan. Pada kelompok ini umumnya mempunyai tingkat kebugaran yang sangat tinggi karena telah dilatih sesuai dengan program yang telah disusun. Kelompok ini dapat melakukan berbagai aktivitas berat secara berkesinambungan selama durasi waktu tertentu. 
Tabel 1

Intensitas latihan sesuai umur (Giam CK \& The KC, 1993)

\begin{tabular}{ccc}
\hline Umur (thn) & $\begin{array}{c}\text { Denyut jantung } \\
\text { maksimal (permenit) }\end{array}$ & $\begin{array}{c}\mathbf{6 5 \%} \text { dari denyut jantung } \\
\text { maksimal (permenit) }\end{array}$ \\
\hline 20 & 200 & $120-170$ \\
30 & 190 & $115-160$ \\
40 & 180 & $110-150$ \\
50 & 170 & $100-145$ \\
60 & 160 & $95-135$ \\
\hline
\end{tabular}

Untuk warga yang ingin menjaga kebugaran dapat melakukan aktivitas 6085 persen dari denyut nadi maksimal dengan frekuensi latihan 3 sampai 5 kali dalam seminggu. Kebugaran jasmani mempunyai beberapa faktor pendukung. Faktor-faktor yang mempengaruhi kebugaran jasmani antara lain : (1) Umur, kebugaran jasmani meningkat maksimal pada usia 25-30 tahun, kemudian akan terjadi penurunan kapasitas fungsional dari seluruh organ tubuh, kira-kira sebesar $0,8-1 \%$ per-tahun, tetapi bila rajin berolahraga penurunan ini dapat dikurangi sampai setengahnya. (2) Jenis Kelamin, sampai pubertas biasanya kebugaran jasmani anak laki-laki hampir sama dengan anak perempuan, tetapi setelah pubertas anak laki-laki biasanya memiliki nilai yang jauh lebih besar. (3) Keturunan/genetik, meliputi kepasitas jantung paru, postur tubuh, obesitas, sel darah dan serat otot. Unsur yang dipengaruhi oleh faktor keturunan diantaranya adalah kemampuan aerobik (VO2 max) sebesar 93\%, sistem asam laktat sebesar $81 \%$, dan denyut jantung maksimal sebesar $86 \%$. (4) Makanan, daya tahan yang tinggi bila mengkonsumsi tinggi karbohidrat (60-70\%). Diet tinggi protein terutama untuk memperbesar otot dan untuk olahraga yang memerlukan kekuatan otot yang besar. (5) Rokok, kadar CO yang dihisap akan mengurangi nilai VO2 max yang berpengaruh terhadap daya tahan dan dapat memperbesar pengeluaran energi serta mengurangi nafsu makan.

Di lingkungan Kelurahan Wonosari terdapat pengaruh yang kurang baik karena beberapa warga tidak memperhatikan pola hidup sehat. Sebagai contoh pada kelompok Usia 0-19 tahun di berbagai RW yang tersebar di wiliyah Kelurahan Wonosari sering terserang berbagai penyakit yang menular seperti: batuk, influenza, demam dan bahkan sakit gigi. Penyakit seperti ini terjadi tidak hanya karena kurang menjaga kebersihan saja, akan tetapi dikarenakan malas melakukan aktivitas fisik dah berolahraga. Pada usia 20-60 tahun masyarakat di Kelurahan Wonosari banyak terserang berbagai macam penyakit seperti: vertigo, 
asam urat dan kolesterol. Pada Lansia usia diatas 60 sering terserang penyakit diabetes mellitus, kolesterol, asam urat dan bahkan penyakit jantung.

\section{HASIL PENDAMPINGAN}

Banyak masyarakat di kelurahan wonosari beranggapan bahwa antara olahraga, aktivitas fisik dan aktivitas jasmani merupakan pengertian yang sama, padahal keduanya memiliki pengertian yang berbeda. Jika pengertian olahraga telah dijelaskan diatas maka aktivitas fisik merupakan gerakan fisik yang dilakukan oleh anatomi tubuh (otot atau muscle, tulang atau skeletal, dll) yang memerlukan pengeluaran energi. Terdapat tiga macam aktivitas fisik yang dapat diterapkan di Kelurahan Wonosari :

1. Aktivitas Ringan : aktivitas yang memerlukan sedikit tenaga dan biasanya tidak memerlukan menyebbkan perubahan pernapasan atau sistem kardiovaskuler. Contohnya jalan santai di waktu pagi atau sore di lingkungan perumahan, berkebun di taman, membersihkan sampah di selokan, menyapu jalan dan lain-lain

2. Aktivitas Sedang : aktivitas yang membutuhkan tenaga secara terus menerus dan berirama. Contohnya: bersepeda di lingkungan perumahan yang mempunyai bukit kecil, berlari-lari kecil, berenang, jalan cepat.

3. Aktivitas Berat : aktivitas yang berhubungan dengan olahraga dan mengakibatkan pengeluaran keringat yang banyak. Contohnya: bermain sepakbola, berlari, senam aerobik, aktivitas outbond.

Tabel 2

Dimensi dan Unsur-unsur aktivitas jasmani pada manusia

\begin{tabular}{|c|c|}
\hline Dimensi & Bentuk Aktivitas \\
\hline \multirow[t]{4}{*}{ Kesadaran tubuh } & $\begin{array}{l}\text { Kesanggupan untuk mengenali bagian-bagian } \\
\text { tubuh dan }\end{array}$ \\
\hline & $\begin{array}{l}\text { manfaatnya bagi gerak. Kesadaran tubuh } \\
\text { memiliki tiga }\end{array}$ \\
\hline & $\begin{array}{l}\text { kesadaran yang terkait dengan aspek } \\
\text { pengetahuan tubuh, } \\
\text { pengetahuan tentang apa yang dapat dilakukan } \\
\text { bagian }\end{array}$ \\
\hline & $\begin{array}{l}\text { tubuh, dan pengetahuan tentang bagaimana } \\
\text { bagian itu } \\
\text { berfungsi. Alangkah baik jika dilatih sejak anak- } \\
\text { anak. }\end{array}$ \\
\hline
\end{tabular}


Kesadaran ruang

Kesadaran arah

Kesadaran tempo
Kemampuan untuk menyesuaikan diri pada posisi diantara

orang lain dan objek lain dalam suatu ruang atau tempat,

juga merupakan kemampuan untuk mengetahui seberapa

luas ruang atau tempat yang digunakan tubuh pada saat

bergerak. Dapat diajarkan dari anak sampai dewasa.

Pemahaman tubuh yang berkenaan dengan tempat dan

arah, terdiri dari dua komponen pemahaman yaitu: 1)

pemahaman internal untuk dapat menggerakkan tubuh ke

samping kanan dan samping kiri (laterality), dan 2)

proyeksi eksternal dari laterality, komponen ini merupakan

pamahaman yang memberikan dimensi ruang.

Kesadaran tempo memungkinkan koordinasi gerakan

antara mata dan anggota tubuh menjadi efisien.

Pengembangan kesadaran tempo berkenaan dengan proses

belajar untuk menyelaraskan gerak dalam sebuah tata urut

yang tepat.

Pemberdayaan masyarakat di Kelurahan Wonosari menjadi tanggung jawab seluruh elemen masyarakat. Pemberdayaan masyarakat adalah kegiatan membangkitkan potensi dan peran aktif masyarakat khususnya masyarakat di Kelurahan Wonosari. Masyarakat di Kelurahan Wonosari memiliki beragam potensi yang dimiliki oleh tiap individu seperti mempunyai bibit atlet berprestasi yang akan mengangkat nama Kelurahan Wonosari. Olahraga merupakan salah satu upaya untuk membuat masyarakat Kelurahan Wonosari yang sehat. Sehat merupakan keadaan sejahtera dari badan, jiwa dan sosial yang memungkinkan setiap orang hidup produktif secara sosial dan ekonomis oleh karena itu, masyarakat yang sehat merupakan tujuan dambaan seluruh elemen masyarakat di 
lingkungan Wonosari. Pemberdayaan masyarakat di kelurahan Wonosari difokuskan pada generasi muda. Pemberdayaan generasi muda merujuk pada ketentuan perundang-undangan yang berlaku, dalam ketentuan umum UndangUndang No. 40 Tahun 2009 Tentang Kepemudaan pasal 1 ayat 6 menyebutkan pemberdayaan pemuda adalah kegiatan membangkitkan potensi dan peran aktif pemuda. Selanjutnya Pasal 17 ayat 3 huruf e bahwa peran aktif pemuda sebagai agen perubahan diwujudkan dengan mengembangkan olahraga, seni dan budaya.

Pada dasarnya kesehatan itu meliputi empat aspek yang saling berkaitan. Aspek (1) Kesehatan fisik terwujud apabila sesorang tidak merasa dan mengeluh sakit atau tidak adanya keluhan terhadap jasmaninya. Semua organ tubuh berfungsi normal atau tidak mengalami gangguan. (2) Kesehatan mental (jiwa) mencakup 3 komponen, yakni pikiran, emosional, dan spiritual. Emosional sehat tercermin dari kemampuan seseorang untuk mengekspresikan emosinya, misalnya takut, gembira, kuatir, sedih dan sebagainya. Spiritual sehat tercermin dari cara seseorang dalam mengekspresikan rasa syukur, pujian, kepercayaan dan sebagainya terhadap sesuatu di luar alam fana ini, yakni Tuhan Yang Maha Kuasa. Semakin banyak kelompok masyarakat di kelurahan Wonosari yang sehat secara spiritual maka akan semakin baik pula lingkungan masyarakatnya. (3) Kesehatan sosial terwujud apabila seseorang mampu berhubungan dengan orang lain atau kelompok lain secara baik, tanpa membedakan ras, suku, agama atau kepercayan, status sosial, ekonomi, politik, dan sebagainya, serta saling toleran dan menghargai. Jika suatu masyarakat mempunyai kesehatan sosial yang baik maka kondisi masyarakat tersebut akan semakin makmur dan sejahtera. (4) Kesehatan dari aspek ekonomi terlihat bila seseorang (dewasa) pada usia produktif, dalam arti mempunyai kegiatan yang menghasilkan sesuatu yang dapat menyokong terhadap hidupnya sendiri atau keluarganya secara finansial. Masyarakat yang mempunyai kelompok manusia yang memiliki kesehatan ekonomi yang baik akan mengakibatkan derajad masyarakat di lingkungan tersebut semakin baik, aka banyak sarana dan prasarana olahraga yang dibangun untuk tujuan menyehatkan anggota masyarakat. Pentingnya aktifitas fisik dan olahraga harus dapat dipahami oleh masyarakat mulai dari anak-anak sampai dengan lansia.

Puskesmas di kelurahan Wonosari mempunyai program yang sangat baik untuk meningkatkan kesehatan warga kelurahan wonsari. Program tersebut diantaranya mensosialisasikan makan teratur dan memperhatikan gizi makan, melakukan aktivitas secara seimbang antara bekerja, belajar dan melakukan olahraga, membiasakan pola tidur yang sehat dan normal selama kurang lebih 78 jam per hari, melarang warga untuk tidak merokok karena rokok berbahaya 
bagi tubuh sendiri dan mengganggu orang lain, tidak mengkonsumsi narkoba dan zat terlarang lainnya, memperhatikan pola makan, tidak mengkonsumsi makanan yang mengandung kolesterol tinggi. Apabila masyarakat wonosari memperhatikan program yang telah disampaikan oleh puskesmas maka diharapkan mempunyai kondisi kesehatan yang baik. Sehat menurut ilmu fisologis dikelompokkan menjadi sehat secara statis dan sehat secara dinamis. Pengertian sehat statis adalah normalnya fungsi alat-alat atau struktur organ dari sistem yang membentuk tubuh pada saat istirahat. Sedangkan sehat secara dinamis normalnya fungsi struktur organ dari sistem yang membentuk tubuh pada waktu bekerja dan atau berolahraga. Orang yang sehat secara dinamis melakukan berbagai aktivitas tanpa terlalu mengalami kelelahan karena. Apabila kita melihat pada manusia penderita penyakit jantung dan sesak napas misalnya, pada keadaan istirahat mereka bisa terlihat sehat (bebas gejala) dan tidak mengalami gangguan kesehatan apapun, akan tetapi ketika bekerja atau berolahraga maka timbul gejala penyakitnya. Sehat dinamis adalah sasaran yang harus kita capai melalui aktivitas fisik atau melalui olahraga karena dengan berolahraga sesungguhnya adalah melatih sistem kardiovaskuler, respirasi, sekresi dan alat-alat tubuh lainnya agar tetap dapat berfungsi dengan normal pada waktu bekerja/ berolahraga, dan pada waktu keadaan istirahat. Jangan sampai mengalami tekanan darah yang tidak stabil.

Perilaku dan Status Kesehatan masyarakat kelurahan Wonosari berkaitan dengan pola kebiasaan perilaku manusia di lingkungan masyarakat wonosari setiap hari. Kebiasaan perilaku yang sehat dapat memberi pengaruh positif terhadap kesehatannya. Kebiasaan yang salah akan memberikan dampak yang negatif. Sehat adalah sejahtera secara jasmani, rohani dan sosial, bukan hanya bebas dari penyakit, cacat atau kelemahan. Keadaan sehat yang demikian agaknya sulit dijumpai oleh karena manusia dalam perjalanan hidupnya senantiasa dihadapkan berbagai ancaman seperti ancaman biologis (penyakit infeksi virus, bakteri dan jamur), kimia ( penyakit alergi, keracunan), fisika (penyakit akibat tekan udara tinggi, radiasi, kecelakaan lalu lintas, kecelakaan kerja), mental (rasa tidak puas, kecewa, sakit hati, dll). Aktivitas fisik bermanfaat untuk kesehatan jasmani, rohani, sosial dan ekonomi. Beberapa manfaat aktivitas fisik bagi manusia antara lain: (1)membantu meningkatkan suasana hati (mood), (2) melancarkan sirkulasi darah dalam tubuh, (3) meningkatkan fungsi organ anatomi yang vital seperti jantung dan paru-paru, (4)menurunkan resiko penyakit jantung, stroke, tekanan darah tinggi, diabetes dan penyakit lainnya. (5) menjaga massa otot dan persendian. (6) dapat menurunkan kecemasan, depresi dan stress. 
Kelurahan wonosari pernah mendapat pendampingan dari beberapa atlet yang tergabung dalam Persatuan Pencak Silat Indonesia Semarang. Pada saat kegiatan tersebut banyak dari remaja yang ikut serta karena merasa tertarik dan tertantang melakukan olahraga pencak silat. Pencak silat juga merupakan olahraga tradisional khas dari Indonesia. Kgiatan tersebut sangat penting karena pada fase remaja olahraga harus menjadi kebutuhan hidup karena pada fase ini remaja cenderung untuk malas melakukan olahraga dikarenakan mudah mendapat pengaruh dari orang lain dan pengaruh dari arus globalisasi yang mengakibatkan mereka malas bergerak. Pada fase remaja mulai dapat berpikir praktis sehingga menyalurkan energi kepada hal yang kurang baik yang mengarah pada kenakalan remaja. Olahraga dapat berfungsi sebagai wadah atau tempat untuk menyalurkan kegiatan positif yang berfungsi sebagai pemberdayaan remaja agar tidak terjerumus pada hal-hal yang tidak baik seperti narkoba, minum minuman keras dan sebagainya.

\section{Tabel 3}

Program aktivitas fisik seluruh elemen masyarakat yang diterapkan di Kelurahan Wonosari

\begin{tabular}{|c|c|c|c|}
\hline Hari & $\begin{array}{c}\text { Jenis Aktivitas Fisik } \\
\text { dan Olahraga }\end{array}$ & $\begin{array}{l}\text { Durasi } \\
\text { Waktu }\end{array}$ & Keterangan \\
\hline Senin & Jalan santai & $30-120$ menit & $\begin{array}{l}\text { Dapat } \\
\text { dilakukan pagi } \\
\text { dan sore hari }\end{array}$ \\
\hline Selasa & Bersepeda & 30-120 menit & $\begin{array}{l}\text { Dapat } \\
\text { dilakukan pagi } \\
\text { dan sore hari }\end{array}$ \\
\hline Rabu & Jalan Santai, permainan & 30-120 menit & $\begin{array}{l}\text { Dapat } \\
\text { dilakukan pagi } \\
\text { dan sore hari }\end{array}$ \\
\hline Kamis & $\begin{array}{l}\text { Bersepeda, bermain } \\
\text { permainan tradisional }\end{array}$ & 30-120 menit & $\begin{array}{l}\text { Dapat } \\
\text { dilakukan pagi } \\
\text { dan sore hari }\end{array}$ \\
\hline Jum'at & Jalan Santai, kegiatan & 30-120 menit & $\begin{array}{l}\text { Dapat } \\
\text { dilakukan pagi } \\
\text { dan sore hari }\end{array}$ \\
\hline Sabtu & Outbond, & & $\begin{array}{l}\text { Dapat } \\
\text { dilakukan pagi } \\
\text { dan sore hari }\end{array}$ \\
\hline Minggu & $\begin{array}{l}\text { Bersepeda, jalan santai, } \\
\text { melakukan }\end{array}$ & $\begin{array}{l}\text { Maksimal } 120 \\
\text { menit }\end{array}$ & $\begin{array}{l}\text { Dapat } \\
\text { dilakukan di }\end{array}$ \\
\hline
\end{tabular}


permainan

lingkungan

perumahan

atau

di

lapangan desa

Kegiatan pendampingan tersebut tidak hanya ditujukan pada remaja akan tetapi ditujukan juga pada orang dewasa. Pada fase dewasa olahraga harus menjadi sebuah kebiasaan atau trendmark untuk menerapkan pola hidup sehat. Olahraga pencak silat dapat dilakukan antara 3 sampai 5 kali dalam seminggu dengan durasi waktu 15-60 menit. Olahraga yang dilakukan dapat menyesuaikan dengan aktivitas pekerjaan sehari-hari sehingga dapat menjaga kebugaran jasmani sehingga akan memiliki kualitas hidup yang baik. Pada fase lansia kebugaran jasmani akan sangat diperlukan. Lansia merupakan fase akhir dalam kehidupan manusia. Manusia mengalami penurunan kemampuan kerja tubuh akibat perubahan fungsi organ-organ tubuh. Lansia dibagi menjadi tiga golongan yaitu: (1) umur lanjut/elderly dengan rentang umur 60-75 tahun, (2) umur tua/old dengan rentang umur 76-90 tahun dan (3) umur sangat tua/very old dengan rentang umur diatas 90 tahun. Lansia sangat dianjurkan untuk melakukan aktivitas fisik selama 30 menit pada intensitas sedang setiap hari. Lansia di Kelurahan Wonosari juga pernah mendapatkan sosialisasi mengenai pentingnya menjaga kebugaran tubuh oleh beberapa pihak dari kecamatan. Lansia diberitahu tentang apa saja kegiatan yang baik dan pas dilakukan oleh lansia. Aktivitas yang dilakukan diantaranya berjalan, berkebuh dan melakukan pekerjaan rumah.

Kondisi sehat merupakan syarat untuk mencapai tingkat kebugaran jasmani yang baik. Kesehatan secara statis maupun dinamis dapat dianalisa dan dinilai secara berkali atau rutin. Penilaian tersebut tinggal melihat pada apa yang telah ditetapkan oleh badan olahraga dan kesehatan dunia (WHO - IOC) sebagai induk kesehatan dunia. Pengukuran kesehatan dapat dilakukan diberbagai tempat seperti di laboratorium maupun di lapangan (pemeriksaan di lapangan dilakukan bila diinginkan hasil yang lebih spesifik). Faktor-faktor tingkat kesehatan yang dinilai sesuai standar WHO meliputi: (1) pemeriksaan fisik (physical examination), (2) pemeriksaan laboratorium klinik dari berbagai fungsi anatomi dan fisiologi organ-organ tubuh. (3) pemeriksaan kemampuan fungsional berbagai organ yang berhubungan dengan sistem energi, baik sub maksimal maupun maksimal. Pemeriksaan fisik yang penting meliputi tidak cacat fisik, serta sistem indra dapat berfungsi dengan baik. Sistem anatomi dan fisiologi yang membentuk tubuh manusia harus dapat berfungsi dengan baik dan 
saling kerja sama satu sama lainnya sehingga terdapat keseimbangan dalam tubuh.

Tabel 4

Klasifikasi Tekanan Darah bagi Orang Dewasa berumur 18 tahun ke atas (American Colleg of Sports Medicine, alih bahasa oleh D S Atmadja dan M Doewes 2004)

\begin{tabular}{ccc}
\hline Sistolik $\mathbf{( m m H g )}$ & Diastolik $\mathbf{( m m H g )}$ & Kategori \\
\hline 130 & $<85$ & Normal \\
$131-139$ & $85-89$ & Normal tinggi \\
$140-159$ & $90-99$ & Hipertensi ringan \\
& & (stadium 1) \\
$160-179$ & $100-109$ & Hipertensi sedang \\
& & (stadium 2) \\
$180-209$ & $110-119$ & Hipertensi (stadium 3) \\
$>210$ & $>120$ & Hipertensi Sangat Berat \\
& & (Stadium 4) \\
\hline
\end{tabular}

\section{KESIMPULAN}

Berbagai permasalahan di lingkungan masyarakat yang bertempat tinggal di Kelurahan Wonosari yang menyebabkan penurunan kualitas hidup bermasyarakat merupakan salah satu akibat dari masuknya arus globalisasi. Pemberdayaan masyarakat di kelurahan Wonosari sangat diperlukan untuk mengatasi permasalahan tersebut. Masyarakat kelurahan Wonosari mulai dari anak-anak, pemuda sampai lansia perlu diberdayakan untuk melakukan kegiatan olahraga. Kegiatan fisik (physical activity) dan olahraga yang dilakukan secara teratur dan berkesinambungan merupakan kegiatan yang sangat bermanfaat untuk menjaga dan meningkatkan kesehatan. Masyarakat di Kelurahan Wonosari telah mempunyai aktivitas fisik atau olahraga yang rutin minimal seminggu 3 kali. Aktivitas tersebut dapat berupa bersepeda, jogging atau lari-lari kecil di pagi dan sore hari di sarana umum, melakukan gerakan skipping, renang, senam aerobik, sepakbola dan badminton.

Aktivitas fisik atau olahraga yang terencana dan teratur yang dilakukan secara rutin, sangat bermanfaat untuk kesehatan dan kebugaran fisik. Sudah saatnya masyarakat kelurahan Wonosari mulai membiasakan untuk melakukan aktivitas fisik yang teratur dan menjadikan aktivitas tersebut sebagai kebutuhan sehari-hari. Olahraga tidak hanya sebagai wadah untuk menyalurkan hobi akan tetapi sebagai pengembangan potensi jasmani, rohani dan sosial agar generasi muda dan anggota masyarakat wonosari lainnya mampu mengembangkan 
dirinya sehingga terhindar dari perilaku menyimpang dan dari pengaruh destruktif yang dapat merusak moral, merusak nilai-nilai sosial karena masyarakat khususnya generasi muda menjadi aset bagi masa depan bangsa dan dapat meningkatkan kualitas masyarakat. Pemerintah juga harus mempunyai peran dalam peningkatan kesadaran berolahraga dengan memperbanyak kebijakan olahraga seperti car free day (CFD) dan memperbanyak sarana dan prasarana olahraga di lingkungan masyarakat wonosari seperti pembangunan lapangan olahraga umum.

\section{DAFTAR PUSTAKA}

Damadi. 2017. Hidup Sehat Dengan Terapi Air Wudhu. Depok: Diandra.

Griwijoyo,S. (2005). Manusia dan Olabraga. Bandung, Penerbit ITB

Gian CK dan Teh KC (1992). Sport Medicine, Exercise and Fitnes. PG Publishing : Singapore.

Hariadi, S.Pd., M.Kes. (2009). Aktivitas Fisike Atau Olahraga Yang Aman Untuk Kesehatan Dan Kesegaran Jasmani. Jurnal Generasi Kampus Volume 2 Nomor 1 April 2009. FIK UNIMED

Kurnianto, Duwi P. (2015). Menjaga Kesehatan Di Usia Lanjut. Yogyakarta : Jurnal Olahraga Prestasi, Volume 11. Nomor 2. Juli 2015.

Lutan, Rusli. (2002). Menuju Sehat Dan Bugar. Jakarta : Depdiknas.

Suharjana. (2013). Kebugaran Jasmani. Yogyakarta: Jogja Global Media.

Sherwood Lauralee (2001). Fisiologi Manusia dari Sel ke Sistem. Edisi ke 2 editor dlm bhs Indo. Beactricia I Santoso. Jakarta : Penerbit Buku Kedokteran EGC.

Sunyoto, Usman. (2004). Pembangunan dan Pemberdayaan Masyarakat. Yogyakarta : Pustaka Pelajar. 
